\title{
Avauksia toimijuuteen aikuiskasvatuksessa
}

\author{
Anneli Eteläpelto, Tuula Heiskanen \& Kaija Collin (toim. 2011). Valta ja toimijuus \\ aikuiskasvatuksessa. Aikuiskasvatuksen 49. vuosikirja. Kansanvalistusseura.
}

TOIMIJUUDESTA ON tullut viime vuosina erityisesti sosiologisesti orientoituneessa tutkimuksessa suosittu teoreettinen kehys, jolla on pyritty tekemään selkoa yhteiskunnallisten rakenteiden, kulttuurin, yhteisöjen ja instituutioiden monimutkaisesta yhteispelistä ihmisten elämän muotouttajina ja toimintamahdollisuuksien rakentajina. Kuten kirjan toimittajat toteavat, "[t] oimijuuden merkitys korostuu yhteiskunnan ja työelämän ajankohtaisissa muutoksissa, joissa ihmisten oman elämän hallinta ja elämänkaaren mielekkääksi rakentaminen edellyttävät entistä vahvempaa yksilöllistä toimijuutta" (s. 5).

Olennaisena osana toimijuuden kysymyksiin kytkeytyy valta. Ei ole suinkaan itsestään selvää, miten "entistä vahvempi yksilöllinen toimijuus" saavutetaan ja kenelle se on mahdollinen. Oli vallassa sitten kyse rakenteellisesta vallasta tai diskursiivisesta hallinnasta, luo valta edellytyksiä toimijuudelle. Se rajoittaa ja mahdollistaa toimijuutta.

Aikuiskasvatuksen 49. vuosikirja tarttuu toimijuuden ja vallan vaikeisiin käsitteisiin ja tarkastelee aikuisten elämän keskeisiä kenttiä - työtä ja koulutusta - näiden käsitteiden ohjaamina. Teos on ensimmäinen suomalainen kokoomateos, jossa pohditaan toimijuutta aikuiskasvatuksen alalla. Kirja koostuu 13 artikkelista sekä toimittajien kirjoittamista avausartikkelista ja yhteenvetoluvusta. Monitieteinen kirjoittajakaarti muodostuu pääasiassa kasvatustieteilijöistä ja työelämäntutkijoista.

Kirja jakautuu kolmeen osioon, joista ensimmäinen käsittelee toimijuutta ja valtaa aikuiskoulutuksessa ja toinen valtaa ja toimijuutta työorganisaatioissa. Kolmannessa osiossa yhdistetään koulutuksen ja työelämän näkökulmat ja analysoidaan, millaisia toimijuuden tiloja aikuisille näissä aikuiselämän keskeisissä konteksteissa rakentuu. Artikkelit valottavat nykyhetken aikuiskoulutuksen ja työelämän kenttää monista näkökulmista ja myös tarkastelujen tasot vaihtelevat koulutuspoliittisista rakenteista yksittäisten ihmisten puheiden hienovaraiseen analyysiin. Erityisen ilahduttavaa teoksessa on yhteisötason analyysit, joissa muun muassa etnografisen tutkimuksen keinoin valotetaan työorganisaatioiden toimintakäytäntöjä ja työntekijöiden epävirallisia hierarkioita. Vallan analyysit tuntuvatkin toimivan parhaiten juuri näissä yhteisötason artikkeleissa, sillä ne avaavat vallan eri muotojen samanaikaista läsnäoloa ja tilanteista vaikutusta toimijuuteen arkielämän käytännöissä.

\section{VAIKUTUSMAHDOLLISUUKSIEN} JA - HALUJEN RISTIRIITA

Kirjan yksi kantavista teemoista ja yksittäiset artikkelit ylittävistä kysymyksistä on aikuisten vaikutusmahdollisuuksien ja vaikutushalukkuuden välillä vallitsevan ristiriidan pohdinta. Jo pidempään on ajateltu, että työssä ja koulutuksessa viihtymisessä ja jaksamisessa keskeistä on kokemus omista mahdollisuuksista vaikuttaa työn ja opiskelun sisältöihin, rytmiin ja ehtoihin. Pyrkimys on ollut kehittää työelämää ja aikuiskoulutusta tähän suuntaan. Tästä huolimatta näyttää siltä, ettei työntekijöitä tai opiskelijoita tunnu kiinnostavan oman työnsä ja osaamisensa kehittäminen siinä määrin, kuin on odotettu. Toimijuuden näkökulmasta tämä on tulkittu siten, etteivät toimijuuden mahdollisuudet kiinnosta työntekijöitä tai koulutuksessa mukana olevia.

Teoksen artikkeleissa onnistutaan lähilukemaan erityisesti yhteiskuntaluokan teoriaa hyväksi käyttäen näitä muutos- ja koulutusvastarinnan tilanteita ja osoittamaan, ettei kyse välttämät- 


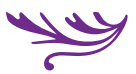

tä ole siitä, ollaanko toimijuuden mahdollisuuksista kiinnostuneita vai ei. Ennemminkin kyse on siitä, millaista tuon kiinnostuksen oletetaan olevan (keskiluokkaista) ja miten kiinnostuksen tulee ilmetä, jotta se tulee tulkituksi kiinnostuksena (akateemisesti), ja siten toimijuutta tuottavana. Samalla tullaan nostaneeksi esiin myös aikuiskasvatuksen ja työelämän ihanteiden keskiluokkaisuus.

Juuri yhteiskunnallisiin eroihin (kuten yhteiskuntaluokka, ikä ja sukupuoli) ja niihin kytkeytyviin normatiivisuuksiin sekä toimijuuden edellytyksiin liittyvää keskustelua voikin pitää kirjan yhtenä keskeisenä ansiona. Ja samalla kompastuskivenä. Kuten kirjan toimittajat toteavat johdanto-artikkelissaan, "[k] atse kääntyy toimijuuden ehtoihin erityisesti silloin, kun toimijuus on puutteellista, rikkoutunutta tai rajoittunutta" (s. 12). Myös valtaosassa kirjan artikkeleissa keskitytään osoittamaan toimijuuden rajoittavia tai estäviä ehtoja. Vaikka rajoitusten analysoiminen on mielekästä, koska se piirtää esiin marginaalissa olevien asemia ja siihen liittyvää normatiivisuutta, olisi myös tärkeää päästä kysymään niitä ehtoja, jotka vallitsevat silloin kun mitään ei puutu, mikään ei rajoita ja kaik- ki on ehjää. Millaisina toimijuuden mekanismit tällöin näyttäytyvät, mikä siis tekee mahdolliseksi normatiivisen toimijuuden?

Olen arvioinut teosta orjallisena sen otsikolle "Valta ja toimijuus aikuiskasvatuksessa" ja tehtävänasettelulle tarkastella "vallan ja toimijuuden eri muotoja aikuisten keskeisillä elämänkentillä: koulutuksessa ja työssä" (s. 23).

Teos havainnollistaa ansiokkaasti, miten moninaisilla tavoilla toimijuus ja valta sekä niiden yhteydet voidaan ymmärtää ja mistä kaikkialta ja millaisin tavoin toimijuutta ja valtaa voidaan analysoida. Teosta vaivaa kuitenkin harmillinen käsitteellinen epätasaisuus. Osassa artikkeleista vallan ja toimijuuden teemat kulkevat eksplisiittisinä läpi artikkelin, mutta toisissa käsitellään pääasiassa jompaakumpaa ja joissakin ei eksplisiittisesti kumpaakaan. Tämä tuottaa katkoksia kirjan eri osien välille ja osien sisään, ja jättää varsinkin toimijuuden ja vallan suhteen kokemattomalle lukijalle liikaa vastuuta sisältöjen linkittämisessä teoreettisiin kysymyksiin. Lukijalle ei riitä, että johdantoartikkelissa avataan keskeiset käsitteet ja loppuluvussa artikkelien tuloksia kootaan yhteen.

Käsitteellisestä epätasaisuu- destaan huolimatta teos on todella tärkeä avaus toimijuuden tematiikkaan aikuiskasvatuksessa. Erityisesti teoksen avausartikkeli tarjoaa toimijuuden ja vallan käsitteistä kiinnostuneelle lukijalle monipuolisen teoreettisen katsauksen. Tästä koonnasta tulevat hyötymään niin opiskelijat kuin tutkijatkin.

Vaikka ei olisikaan erityisen kiinnostunut toimijuuden ja/ tai vallan kysymyksistä, teos antaa monipuolisuutensa ja vahvan empiirisen otteensa vuoksi paljon ajateltavaa aikuiskasvatuksen ja työelämän nykyisistä virtauksista. Kirja tarjoaa myös joitakin suoraan käytäntöön sovellettavia työvälineitä. Yhteiskunnallisista eroista (yhteiskuntaluokka, ikä ja sukupuoli) kiinnostuneelle lukijalle teos tarjoilee mojovan paketin sekä sisällöllisiä aikalaisanalyysejä että metodologisia vinkkejä erojen luentaan. Aikuiskasvatuksen 49. vuosikirjalla on kaikki ainekset herättää kriittistä keskustelua aikuiskoulutuksen ja työelämän nykymenosta. Siksi toivonkin, että teos tavoittaisi mahdollisimman laajan lukijakunnan.

Hanna Ojala

tutkijatohtori, tutkijakollegium, Tampereen yliopisto 